\title{
Seeking Solution To Software Piracy In Teacher Education In An Age Of ICT
}

\author{
Nwana S. E., Ph.D., LL.B \\ Faculty of Education, Nnamdi Azikiwe University \\ Awka, Nigeria \\ Ugwuda S. O., Ph.D. \\ University Of Nigeria, Nsukka
}

\begin{abstract}
The paper focuses on software piracy in teacher education. In this age of Information and Communications Technology (ICT) various software are used for teaching learning effectiveness and many of them an reproduced by software pirates. In this paper, the concepts of teacher education, ICT and computer software were explained. Types of computer software were listed and explained. It highlighted software production and originality of works, under section 51 of the Copyright Act Cap. C 28 Laws of the Federation 2004. It defined piracy. It examined copyright and enumerated the things that constitute infringement of copyright as provided in section 15 (1) (a-g) copyright Act Cap. C 28 Laws of the Federation 2004. Finally, the paper stated legal remedies for curbing software privacy in teacher education. Also, it stated various way forward such as provision of storage facilities, software library and software encryption.
\end{abstract}

Key words: Piracy, ICT, Teacher Education, software

\section{INTRODUCTION}

Information and Communications Technology (ICT) uses the internet which is the fastest aspect of it to create unlimited opportunities for educational, commercial, industrial and social activities. In education for instance, one can access the internet to down load education sites e.g. UNESCO, education files, curriculum materials, examination results, online questionnaire and software applications. Others are virtual library, virtual classroom, virtual laboratory, online collaborative studies, online research and finding of human resources in various fields of learning. In commercial activities for instance, the internet enables the use of the Automated Teller Machine (ATM) in bank transactions. With the ATM, cash deposits and withdrawals are made.

The net as we can see, has a lot of liberal security holes. Information can miss way from one computer to another; and there may be interception at any time. This is because the File Transfer Protocol (FTP) which transfers files from one computer to another does not query the data/information being transferred (Nwana, 2008). This leads to various software theft, software piracy and cyber crimes in various sectors of the society including teacher education.

Teacher education is education of teachers for the acquisition of necessary knowledge, skills, methodologies, strategies, abilities and professional competencies to teach at all levels of education namely nursery, primary, secondary and tertiary levels. Teacher education by extension includes the training and production of teachers who will serve in other professional areas of education as educational administrators, educational planners, policy-makers and 
supervisors among others. Mbakwem (2005) pointed out that, teacher education encompasses all such programmes which are designed to give professional training to those who will be engaged in teaching; and to all those who will be involved in other professional activities of education.

Teacher education is the foundation of quality, functional and effective education. This is why Federal Republic of Nigeria (FRN, 2014 p.38) stated that, "No education system can rise above the quality of its teachers". In this age of ICT, hardware such as computer, printer and scanner are used in teacher education. Others are software such as CD-Rom, discs, slides and flash memories. There are ready-made and teacher developed software but the problem is that they are pirated after development and production. The level of piracy is on the increase and it posses a problem in teacher education.

Computer software piracy poses a big threat to teacher education and research, it carries in its train, computer - assisted crimes namely distribution of software viruses and worms, theft of data, e-mail scams, hacking and cracking of information by hackers and crackers. Therefore, there is need to protect computer software in teacher education. It is not just enough to have ICT knowledge but ICT intelligence agency which works with the security agencies to combat software crimes.

\section{WHAT IS ICT?}

ICT stands for Information and Communications Technology. It is a network of networks and web of webs of which like a spiders web disseminates information all over the world. Nwana (2008; \& 2012) defined ICT as the science of information processing which deals with the use of computers and other electronic devices to collect, process, store, retrieve and transmit or disseminate information to any part of the world.

Nwana, Ugwoegbu and Adebola (2010) stated that, ICT is the most advanced, sophisticated and fastest form of technology which has brought the world into a global village. It has various communication technologies namely: the internet, e-mail, computer networks and websites, satellites and cable devices, microwaves, hardware and software packages. All these are needed for functional and effective curriculum implementation in teacher education. Also, in the National Policy on Education, (FRN, 2014) defined ICT as a product of technological change and an innovation in education.

In education, ICT performs the roles of downloading and uploading of education files, curriculum materials, use of e-mail, online library, online collaborative studies, online research, online peer review, online admission and registration of students, online publishing of examination results, online transfer of records, downloading of education films e.g Things Fall Apart by Chinua Achebe, finding software applications, finding of resource persons and online academic conferencing (Mkpa, 2010; Nwana, 2008; \& Sharp, 2005).

\section{WHAT IS COMPUTER SOFTWARE?}

Computer software is a collective name for all programs which the user uses for handling several and voluminous problems in various fields of human endeavour. Computer software also describes all programs used in a computer as recorded on auxiliary or secondary devices e.g tapes and discs. Nwosu (2002) pointed out that, in computer systems technology, software is the opposite of hardware; and that it is the cream, the operational milk or the nervous system of the hardware component, stressing that without the software, the hardware becomes an insignificant and useless lump of metal. On the other hand, section 51 Copyright Act Cap. C 28 Laws of the Federation 2004 defined computer software (programs) as, a set of 
statements or instructions to be used directly or indirectly in a computer to bring a certain result. Software appear in various forms namely: systems software, applications software and secondary /auxiliary software.

\section{Types of Computer Software}

According to Nwana (2009) and Nwosu (2002), there are three major types of software namely: systems software, applications software and secondary software.

i. $\quad$ Systems software: They are the software that are in-built in the computer system. They come with the computer in order to facilitate the use of the hardware. Some examples of systems software are: operating systems software, data base software, and language translating software.

ii. Applications software: They are pre-written programs that are used to solve a particular business or scientific task. They may be modified and loaded into the computer by the individual user. Examples are: word processing software graphics software, spreadsheet software, communications (web) software and virus software.

iii. Secondary software: They are software which contain recorded information for retrieval and use when the need arises. Examples are CD-ROM, flash drives, slides, films and transparencies. Others are tapes, floppy disk, magnetic disk, optical disks, video disk, magnetic drum, magnetic cards and punch cards (Nwosu, 2002).

\section{SOFTWARE PRODUCTION AND ORIGINALITY OF WORKS}

Computer software is a work. It is work produced by somebody. For instance, if you have produced or originated a work and recorded it in a CD-ROM, you are the author and the original owner. Section 51 of the Copyright Act Cap. C 28 Laws of the Federation 2004 defines a "work" as any translations, adaptation, new versions or arrangements of pre-existing works and anthologies or collection of works which by reason of the selection and arrangement of their content, present an original character. The term "original" means that the work must be new or innovative. Originality is more concerned with the manner in which the work was created and is usually taken to be that the work in question originated from the author, its creator, and that it was not copied from another work.

The term "work" under section 1(1) of the Copyright Act Cap. C 28 Laws of the Federation 2004 embraces Literary, musical and artistic works, cinematograph films, sound recordings and broadcasts.

- Literary work includes, irrespective of literary quality, any of the following works or works similar thereto:

a) Novels, stories and poetical works;

b) Plays, stage directions, films scenarios and broadcasting scripts;

c) Choreographic works;

d) Computer programmes;

e) Textbooks, treatises, histories, biographies, essays and articles;

f) Encyclopedias, dictionaries, directories and anthologies;

g) Letters, reports and memoranda;

h) Lectures, addresses and sermons;

i) Law reports, excluding decisions of courts;

j) Written tables or compilation.

- Musical work means any musical composition, irrespective of musical quality and includes works composed for musical accompaniment. 
- Artistic work includes, irrespective of artistic quality, any of the following work or works similar thereto:

a) Paintings, drawings, sketching, lithographs, woodcuts, engravings and prints;

b) Maps, plans and diagrams;

c) Works of sculpture;

d) Photographs not comprised in a cinematograph film;

e) Works of architecture in the form of buildings models; and

f) Works of artistic craftsmanship and also (subject to subsection (3) of section 1 of this Act) pictorial woven tissues and articles of applied handicraft and industrial art.

- Cinematograph film includes the first fixation of a sequence of visual images capable of being shown as a moving picture and of being the subject or reproduction, and includes the recording of a sound track associated with the cinematograph film.

- Sound recording means the first fixation of a sequence of sound capable of being perceived aurally and of being reproduced, but does not included a sound track associated with a cinematograph film.

- Broadcast means sound or television broadcast by wireless telegraph or wire or both, or by satellite or cable programmes and includes rebroadcast.

\section{WHAT IS SOFTWARE PIRACY?}

Software piracy is the illegal copying, distribution or use of software. It is unauthorized copying of a work developed and produced by somebody. The Oxford Advanced Learner's Dictionary defined software piracy as the act of making illegal copies of DVDs, computer programmes, books etc in order to sell them. The internet.bsa.org defined software piracy as the unauthorized copying or distribution of copyrighted software; copying, downloading, sharing, selling or installing multiple copies of software into personal or work computers. Software piracy is infringement of copyright.

\section{Types of Software Piracy}

1. Counterfeiting: Duplicating and selling unauthorized copies as legitimate copies.

2. Internet piracy: Online/virtual piracy

3. Stealing and installing: Stealing of original work, installing it in a system and pirating it.

4. End-User piracy: Pirating and keeping for personal use.

5. Borrowing and installing: Borrowing of original work, installing it in a system and pirating it.

6. Client - Server Piracy: The client pirates from the computer server. Servers are large computer networks for internet cruising while clients are computers which access the server.

7. Retail Piracy: Pirating and selling on retail basis.

8. Hard disk piracy: Pirating a work loaded in a hard disk and installing it in another system.

\section{WHAT IS COPYRIGHT?}

The Black's Law Dictionary (2009) defined copyright as, the rights or literary property as recognized and sanctioned by positive law. An intangible incorporeal right granted by statute to the author or originator of certain literary or artistic productions, whereby he is invested for a limited period, with the sole and exclusive priviledge of multiplying copies of the same and publishing and selling them. 
The Osborn's Concise Law Dictionary (2003) defined copyright as, the exclusive right of printing or otherwise multiplying copies of, inter alia, a published literary work; that is, the right of preventing all others from doing so.

From the definitions, copyright is the right given to the original owner of a work in order to exclude others from substantial copying of the material form of the work.

\section{WHAT IS INFRINGEMENT OF COPYRIGHT?}

Copyright infringement comes up where somebody indulges in the acts restricted by Copyright Act that is, primary infringement as provided in S. 15 (1) (a-g) Copyright Act Cap. C 28 Laws of the Federation 2004. Again, copyright infringement comes up where a person deals with infringing copies of a work without the licence or permission of the copyright owner. This is called secondary infringement. The Black's Law Dictionary defined infringement as, a breaking into, a trespass or encroachment upon a violation of the law, regulation, contract or right. The Osborn's Concise law Dictionary defined infringement as, interference with, or the violation of the right of another, particularly the right to a patent of copyright. However, there are exception to copyright infringement. For instance, where a person comes to borrow a book from you, and you lend it to the person, it does not infringe copyright. Also, making an artistic work from a literary work does not infringe copyright.

Section 15 (1) Copyright Act Cap. C 28 Laws of the Federation 2004 provides that the right of the copyright owner, will be deemed to be infringed by any person, who, without the licence or authorization of the owner of the copyright, does any or the following acts, viz:

a) does, or causes any other person to do an act, the doing of which is controlled by copyright;

b) Imparts or causes to be imported into Nigeria any copy of a work which, if it had been made in Nigeria, would be an infringing copy under this section of this Act;

c) Exhibits in public any article in respect of which copyright is infringed under paragraph (a) of this subsection;

d) Distributes by way of trade offers for sale, his or otherwise or for any purpose prejudicial to the owner of the copyright, any article in respect of which copyright is infringed under paragraph (a) of this subsection;

e) Makes or has in his possession plates, master tapes, machines, equipment or contrivances used for the purpose of taking infringed copies of the work;

f) Permits a place of public entertainment or of business to be used for a performance in the public of the work, where the performance constitutes an infringement of the copyright in the work, unless the person permitting the place to be so used was not aware, and had no reasonable ground for suspecting that the performance would be an infringement of the copyright.

g) Performs or causes to be performed, for the purposes of trade of business or as supporting facility to a trade or business, any work in which copyright subsists.

\section{THE WAY FORWARD}

\section{Legal Remedies to Software Piracy}

The remedies in civil or criminal proceedings or both which are available to an aggrieved copyright owner that is, a person whose work have been pirated as provided in the Act and as citied by authors in Intellectual Property Law e.g Babafemi (2007) are as follows: Damages, Injunction, Anthon Piller Order, Account of Profits and Right of Conversion. 


\section{Damages}

Damages are divided into general/special, exemplary/punitive and nominal damages. General damages are the losses which flow naturally from the defendants conduct and its quantum need not be pleaded or proved as it is generally presumed by law. Special damages are the damages which the law does not presumed but must be specifically pleaded and proved. Exemplary/punitive damages are not intended to compensate the plaintiff but to punish the defendant and to deter him from similar behaviour in the future. Nominal damages are awarded where the plaintiff establishes a violation of his rights by the defendant but he is unable to show that he suffered any actual damages as a result of the defendant's wrongdoing. Also, it may be awarded where damages have been proved but no evidence has been given as to its extent so that the assessment of compensatory damage becomes a mission impossible.

\section{Injunction}

It is granted by the court to prevent a person from doing an act or to prevent him from continuing to do a wrong. It is also used to compel a person to perform an act.

\section{Anton Piller Order}

This is an order given for inspection, photographing and delivery up of infringing materials in the possession or control of an infringer.

\section{Account of Profit}

In this case, the plaintiff is entitled to the profit on each item wrongly sold. The court often compels the defendant to pay to the plaintiff the amount of profit he earned when he (the defendant) was selling the infringing copies.

\section{Right of Conversion}

Conversion rights are as well available to a party whose rights have been infringed.

\section{Others:}

a. Provision of storage facilities: The government should provide teacher education institutions with good storage facilities for safe keeping of all manner of software used in teaching - learning situation.

b. Provision of Software library: There is need for software library to be provided in teacher education institutions. In this type of library, only software are kept and only people of clear identities are allowed to use it.

c. Software Encryption: There is need for software encryption or security especially for materials that can be accessed on the internet. Special passwords can be used to secure them. Firewalls may be created as special security for protection of software in teacher education. This will go a long way to curbing the menacing activities of software pirates.

\section{CONCLUSION}

ICT stands for Information and Communications Technology. It is a web of webs and network of networks which links millions of computer users all over the world. The internet as an aspect of ICT has liberal security holes because of that, there are a lot of computer crimes which includes software piracy or copyright infringement. This is already a big threat to education. The need for legal protection of computer software in teacher education is on the increase. It is not just enough to have ICT knowledge and use it for downloading and uploading of curriculum materials or for online admission and registration of students to mention but a few but there is need for security agencies to check software piracy. Since the three major types of software namely systems software, Applications software and secondary software are 
used in teacher education, there is need for its security and legal protection from the hands of infringers or software pirates.

It is recommended as follows:

\section{RECOMMENDATIONS}

1. That the government should create Software Security Agency that will arrest and prosecute infringers.

2. That the government should introduce a course to be titled "introduction to copyright law" at the secondary and tertiary levels of education so that people will understand the legal implications of computer software piracy.

3. The Nigerian Copyright Commission should organize seminars, workshops and conferences to enlighten people on the legal implications of infringement of computer software and copyright in general.

4. The government should create a crop of copyright inspectors that will ground to various business premises particularly software production industries, publishing houses and photocopying centres to check the activities of computer software pirates.

5. The government should duly accredit various computer software coming into the country so as to intercept fake copyright products and to avoid their use in teacher education.

\section{References}

Babafemi, F.O. (2007). Intellectual property in Nigeria. Ibadan: Justian Book Pub.

Bird, R. (2003). Osborn's Concise Law Dictionary. London: Sweet \& Maxwell Pub.

Copyright Act Cap. C 28 Laws of the Federation 2004.

Federal Republic of Nigeria (2014). National Policy on Education. Lagos; NERDC press

Garner, B.A. (2009). Blacks Law Dictionary. USA: St Paul Minn West Pub.

Hornby, A.S. (2014). Oxford Advance Learners Dictionary.

Mbakwem, J.N. (2005). New Perspectives to teacher education. Owerri: Hudosn Jude Pub.

Mkpa, M.A (2010). Innovation and issues in primary and teacher education in Nigeria. Journal of Teacher Education and Teaching. 8(1), 1-11.

Nwana, S.E. (2008). Information and Communication Technology -ICT: A continuity in educational technology. Onitsha: West \& Solomon Pub.

Nwana, S.E (2008). Information and Communications Technology (ICT) in education: The place of teleconferencing. Journal of Adult Education Studies ( JAES). 3 (1), 86-91.

Nwana, S.E. (2009). Educational Technology in Digital Age. Awka: Kristophel pub.

Nwana, S.E; Ugwoegbu, I.T; \& Adebola, H.E.) (2010). Information and communication technology: A new trend for engineering functionality in curriculum and instruction. International Journal of Research in Education (IJRE). 2 (6), 10-14.

Nwana, S.E. (2012). Challenges in the application of e-learning by secondary school teachers in Anambra State, Nigeria. African Journal of Teacher Education (AJOTE). 2 (1), 14-22.

Nwana, S.E. (2012). Availability and use of ICT resources by lecturers for teaching and learning in Faculty of Education, Unizik, Awka. Unizik Orient Journal of Education. 6 (1), 256-280.

Nwosu S.E. (2002). Fundamentals of computer education and educational technology. Enugu: Cedartop Pub.

Sharp, V. (2005). Computer education for teachers: Integrating technology into classroom teaching. Boston: McGraw- Hill.

Software piracy. Accessed from Internet bsa.org, $4^{\text {th }}$ October, 2016. 